\title{
Identification of new autoantibody specificities directed at proteins involved in the transforming growth factor $\beta$ pathway in patients with systemic sclerosis
}

Guillaume Bussone ${ }^{1,2}$, Hanadi Dib ${ }^{1,2}$, Mathieu C Tamby ${ }^{1,2}$, Cedric Broussard ${ }^{3}$, Christian Federici ${ }^{3}$, Geneviève Woimant ${ }^{4}$, Luc Camoin ${ }^{3}$, Loïc Guillevin ${ }^{5}$ and Luc Mouthon ${ }^{1,2,5^{*}}$

\begin{abstract}
Introduction: Antinuclear antibodies (ANAs), usually detected by indirect immunofluorescence on HEp-2 cells, are identified in $90 \%$ of patients with systemic sclerosis (SSC). Thus, approximately $10 \%$ of SSc patients have no routinely detectable autoantibodies, and for $20 \%$ to $40 \%$ of those with detectable ANAs, the ANAs do not have identified specificity (unidentified ANAs). In this work, we aimed to identify new target autoantigens in SSc patients.

Methods: Using a proteomic approach combining two-dimensional electrophoresis and immunoblotting with HEp-2 cell total and enriched nuclear protein extracts as sources of autoantigens, we systematically analysed autoantibodies in SSC patients. Sera from 45 SSc patients were tested in 15 pools from groups of three patients with the same phenotype. A sera pool from 12 healthy individuals was used as a control. Proteins of interest were identified by mass spectrometry and analysed using Pathway Studio software.

Results: We identified 974 and 832 protein spots in HEp-2 cell total and enriched nuclear protein extracts, respectively. Interestingly, $\alpha$-enolase was recognised by immunoglobulin $\mathrm{G}(\mathrm{lgG})$ from all pools of patients in both extracts. Fourteen and four proteins were recognised by lgG from at least $75 \%$ of the 15 pools in total and enriched nuclear protein extracts, respectively, whereas 15 protein spots were specifically recognised by IgG from at least four of the ten pools from patients with unidentified ANAs. The IgG intensity for a number of antigens was higher in sera from patients than in sera from healthy controls. These antigens included triosephosphate isomerase, superoxide dismutase mitochondrial precursor, heterogeneous nuclear ribonucleoprotein $L$ and lamin $A / C$. In addition, peroxiredoxin 2, cofilin 1 and calreticulin were specifically recognised by sera from phenotypic subsets of patients with unidentified ANAs. Interestingly, several identified target antigens were involved in the transforming growth factor $\beta$ pathway.
\end{abstract}

Conclusions: We identified several new target antigens shared among patients with SSC or specific to a given phenotype. The specification of new autoantibodies could help in understanding the pathophysiology of SSc. Moreover, these autoantibodies could represent new diagnostic and/or prognostic markers for SSc.

\footnotetext{
* Correspondence: luc.mouthon@cch.aphp.fr

${ }^{1}$ Institut Cochin, Université Paris Descartes, CNRS UMR 8104, 8 rue Méchain,

F-75014 Paris, France

Full list of author information is available at the end of the article
} 


\section{Introduction}

Systemic sclerosis (SSc) is a connective tissue disorder characterised by excessive collagen deposition in the dermis and internal organs, vascular hyperreactivity and obliteration phenomena [1]. A large number of autoantibodies have been identified in the sera of SSc patients. Antinuclear antibodies (ANAs), usually detected by indirect immunofluorescence on HEp-2 cells, are identified in $90 \%$ of patients [2]. Some of them are diseasespecific and mutually exclusive: anticentromere antibodies (ACAs), associated with limited cutaneous SSc (lcSSc) and possibly pulmonary arterial hypertension (PAH); anti-topoisomerase I antibodies (ATAs), associated with diffuse cutaneous SSc (dcSSc) and interstitial lung disease (ILD); and anti-RNA polymerase III antibodies, associated with dcSSc and scleroderma renal crisis (SRC) [3]. In addition, other autoantibodies have been found in the sera of SSc patients and include antifibrillarin, antifibrillin 1, anti-Th/To, anti-PM/Scl [3], antifibroblast [4-6] and anti-endothelial cell antibodies [7-9]. Overall, the only specific autoantibodies routinely tested for in SSc patients are ACAs, ATAs and, more recently, anti-RNA polymerase III antibodies.

Thus, approximately $10 \%$ of SSc patients have no routinely detectable autoantibodies, and for $20 \%$ to $40 \%$ of those with detectable ANAs, the nuclear target antigens of these ANAs have not been identified [2]. Therefore, further work is warranted to better determine the disease subset and prognosis for these patients. The specification of new autoantibodies could help in understanding the pathophysiology of SSc and reveal new diagnostic and/or prognostic markers.

Using a proteomic approach combining two-dimensional electrophoresis (2-DE) and immunoblotting, we recently identified target antigens of antifibroblast antibodies in patients with PAH [10]. In this work, using a similar proteomic approach with total and enriched nuclear protein extracts of HEp-2 cells as sources of autoantigens, we systematically analysed autoantibodies in SSc patients and identified a number of new target antigens for these autoantibodies.

\section{Materials and methods Immunoglobulin sources}

Sera were obtained from 45 patients who fulfilled the LeRoy and Medsger criteria and/or the American Rheumatism Association criteria for the diagnosis of SSc. Sera were tested in 15 pools from groups of three patients with the same phenotype as described previously [10]. Four pools were from patients with identified ANAs (that is, ACAs, ATAs or anti-RNA polymerase III antibodies), ten pools were from patients with unidentified ANAs, and one pool was from patients without ANAs (Table 1). The sera from three patients with anti-RNA polymerase III antibodies who had experienced SRC were included in one of the two pools from patients with SRC. ANAs and ACAs were investigated by indirect immunofluorescence on HEp-2 cells; ACAs were characterised by a centromere pattern; ATAs and anti-RNA polymerase III antibodies were detected by using an enzyme-linked

Table 1 Characteristics of pools of sera used as sources of $\operatorname{lgG}^{a}$

\begin{tabular}{llc}
\hline Main clinical characteristics & Autoimmunity & Number of pools tested $^{\mathbf{b}}$ \\
\hline $\begin{array}{l}\text { Healthy blood donors } \\
\text { dcSSC }\end{array}$ & No ANA & 1 \\
$\quad$ No visceral involvement & No ANA & 1 \\
Interstitial lung disease & ATA & 1 \\
Scleroderma renal crisis & Anti-RNA-pol III Abs & 1 \\
IcSSC & ACA & 1 \\
Pulmonary arterial hypertension & ACA & 1 \\
No visceral involvement & ANA with unidentified specificity & 1 \\
dcSSC & ANA with unidentified specificity & 1 \\
Scleroderma renal crisis & ANA with unidentified specificity & 2 \\
Pulmonary arterial hypertension & ANA with unidentified specificity & 1 \\
Interstitial lung disease & ANA with unidentified specificity & 1 \\
No visceral involvement & ANA with unidentified specificity & 1 \\
Digital ulcers & ANA with unidentified specificity & 1 \\
Pulmonary arterial hypertension & ANA with unidentified specificity & 1 \\
Interstitial lung disease & No visceral involvement
\end{tabular}

${ }^{a}$ Abs: antibodies; ACA: anticentromere antibody; ANA: antinuclear antibody; anti-RNA-pol III Abs: anti-RNA polymerase III antibodies; ATA: antitopoisomerase I

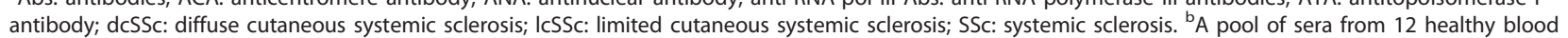
donors was tested as a control. Immunoglobulin G reactivities were tested in pools of three sera from patients with the same phenotype of SSc. 
immunosorbent assay (ELISA) kit (INOVA Diagnostics, San Diego, CA, USA).

We used a pool of sera from 12 healthy blood donors as a control. Healthy controls (HCs) had no detectable disease, no remarkable medical history and no ANAs and were not taking any medication at the time of blood sampling. Serum samples were stored in aliquots at $-80^{\circ} \mathrm{C}$.

All patients and HCs gave their written informed consent according to the policies of the ethics committee of Cochin Hospital. They were included in the Hypertension Artérielle Pulmonaire (HTAP)-Ig study (Investigation and Clinical Research's contract 2005, CIRC 05066, promoter Assistance Publique-Hôpitaux de Paris).

\section{HEp-2 cell culture}

HEp-2 cells, a cell line derived from a human laryngeal carcinoma, were obtained from EuroBio (Les Ulis, France) and cultured as described previously [8]. When confluent, the cells were detached by use of $0.05 \%$ trypsin-ethylenediaminetetraacetic acid (EDTA) (Invitrogen, Carlsbad, CA, USA).

\section{Protein extraction}

Total proteins were extracted from HEp-2 cells as described previously [11]. Briefly, HEp-2 cells were suspended in a sample solution extraction kit (Bio-Rad Laboratories, Hercules, CA, USA) containing 2\% (wt/vol) sulfobetaine zwitterionic detergent (SB 3-10) and the carrier ampholyte Bio-Lyte 3/10 (Bio-Rad Laboratories). Cell samples were sonicated on ice, and the supernatant was collected after ultracentrifugation. Finally, after protein quantification [12], 64 $\mathrm{mM}$ dithiothreitol (Sigma-Aldrich, St. Louis, MO, USA) was added, and the supernatant was aliquoted and stored at $-80^{\circ} \mathrm{C}$.

A protein extract enriched in nuclear proteins was obtained as previously described [13], which is referred to hereinafter as enriched nuclear protein extract. Briefly, HEp-2 cells were suspended in a buffer containing $10 \mathrm{mM}$ 4-(2-hydroxyethyl)-1-piperazineethanesulfonic acid (HEPES), pH 7.9, $10 \mathrm{mM} \mathrm{KCl,} 0.1 \mathrm{mM}$ EDTA, $0.1 \mathrm{mM}$ ethyleneglycoltetraacetic acid (EGTA), $1 \mathrm{mM}$ dithiothreitol and antiproteases. After incubation for 15 minutes on ice, $10 \%$ Nonidet P-40 (Sigma-Aldrich) was added and cells were vortexed. Cells were then resuspended, incubated for 15 minutes on ice and regularly vortexed in a buffer containing $20 \mathrm{mM}$ HEPES, pH 7.9, $0.4 \mathrm{M} \mathrm{NaCl}, 1 \mathrm{mM}$ EDTA, $1 \mathrm{mM}$ EGTA, $1 \mathrm{mM}$ dithiothreitol and antiproteases. After ultracentrifugation, the supernatant was washed in a precooled $\left(-20^{\circ} \mathrm{C}\right)$ solution of $10 \%$ trichloroacetic acid in acetone with $0.07 \%$ 2-mercaptoethanol (Sigma-Aldrich) to eliminate salts as described previously [13]. Proteins were resuspended in the sample solution extraction kit and then quantified [12]. Finally, $64 \mathrm{mM}$ dithiothreitol was added, and the sample was aliquoted and stored at $-80^{\circ} \mathrm{C}$.

\section{Two-dimensional electrophoresis}

The study protocol is depicted in Figure 1. We used a pH range of 3.0 to 10.0 and an acrylamide gradient of $7 \%$ to $18 \%$, which allowed us to study a wide range of antigens of 10 to $250 \mathrm{kDa}[11,14]$. Proteins were isoelectrofocused with $17-\mathrm{cm}$ immobilised $\mathrm{pH}$ gradient strips on the Protean IEF Cell System (Bio-Rad Laboratories) as described previously [11]. Thus, $100 \mu \mathrm{g}$ of HEp-2 cell proteins from total or enriched nuclear protein extracts were loaded onto each strip. Before the second dimension, the strips were equilibrated and then proteins were transferred to gels as described previously $[11,13]$. Finally, one gel was stained with ammoniacal silver nitrate to serve as a reference for analysis of 2-D immunoblots [14].

\section{Electrotransfer and immunoblotting}

After migration, proteins were transferred onto polyvinylidene difluoride membranes (Millipore, Billerica, MA, USA) by semidry transfer (Bio-Rad Laboratories) at 320 $\mathrm{mA}$ for 90 minutes. After being blocked, membranes were incubated overnight at $4^{\circ} \mathrm{C}$ with each of the sera pools from HCs and patients at a 1:100 dilution. Immunoglobulin G (IgG) immunoreactivities were revealed as described previously [11]. Specific reactivities were determined by densitometrically scanning the membranes (GS-800 calibrated densitometer; Bio-Rad Laboratories) with Quantity One software (Bio-Rad Laboratories). The membranes were then stained with colloidal gold (Protogold; British Biocell International, Cardiff, UK) and underwent secondary densitometric analysis to record labelled protein spots for each membrane.

Images of the reference gel and membranes were acquired by using the GS- 800 calibrated densitometer and were analysed by using ImageMaster 2D Platinum 6.0 software (GE Healthcare, Buckinghamshire, UK) as described previously [11].

\section{In-gel trypsin digestion}

Relevant spots were selected by comparing the 2-D immunoblots with the silver-stained reference gel and then extracted from another gel stained with Coomassie brilliant blue (Sigma-Aldrich). In-gel digestion involved the use of trypsin as described previously [13], and for all steps a Freedom EVO 100 digester/spotter robot was used (Tecan, Männedorf, Switzerland).

\section{Protein identification by mass spectrometry}

Protein identification involved the use of a matrixassisted laser desorption/ionization time of flight (MALDI-TOF)-TOF 4800 mass spectrometer (Applied 


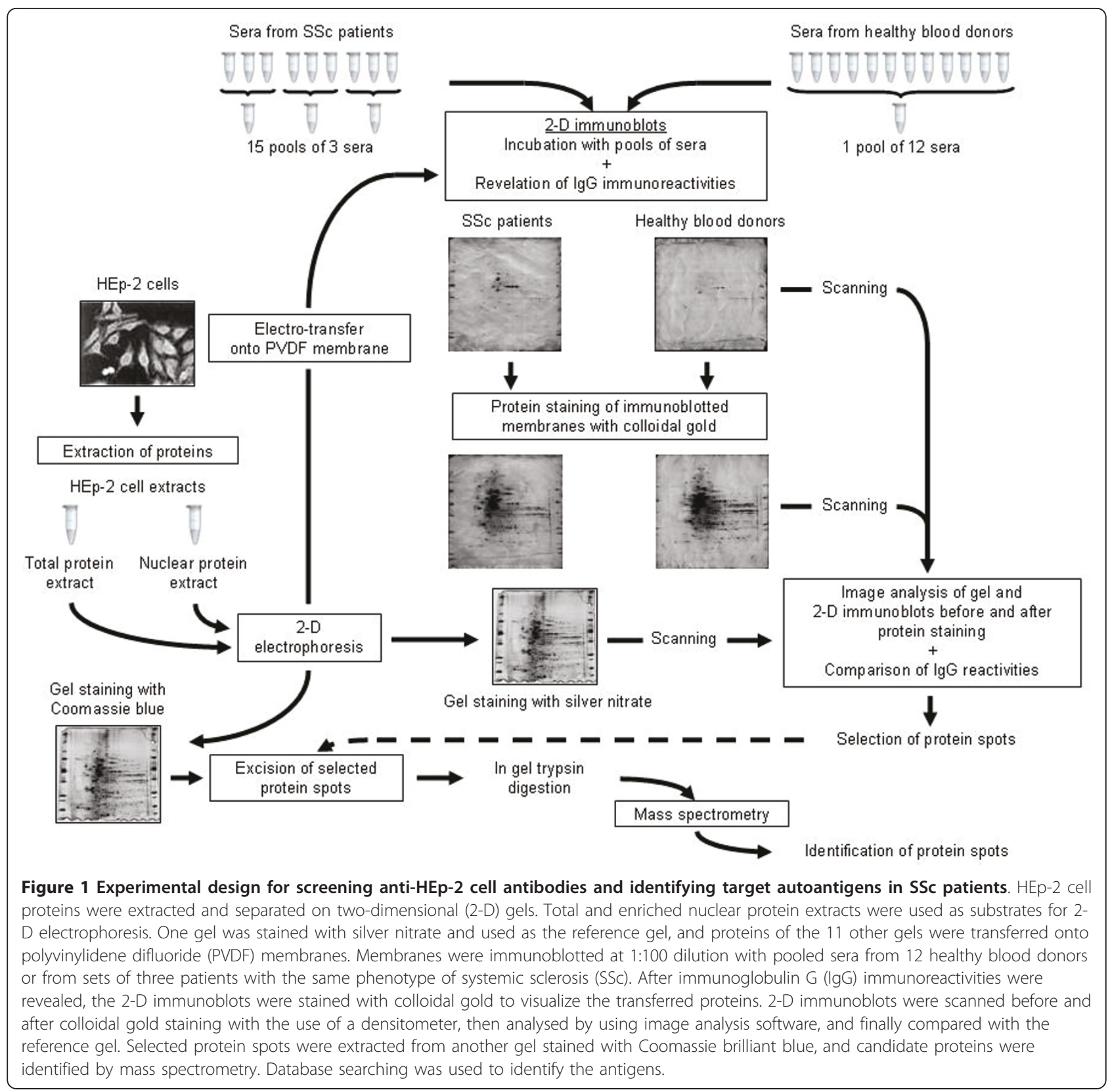

Biosystems, Foster City, CA, USA) as previously reported [13]. Database searching involved the use of Mascot 2.2 software (Matrix Science, London, UK) and the GPS Explorer version 3.6 program (Applied Biosystems) to combine mass spectrometry (MS) and tandem mass spectrometry (MS/MS) queries of human proteins from the Swiss-Prot database [15].

\section{Biological network analysis}

Protein lists of interest were analysed using Pathway Studio software (Ariadne, Rockville, MD, USA) [16].
Pathway Studio is a pathway analysis tool that uses automated text-mining engines to extract information from the literature. Briefly, protein lists were run against ResNet 7.0, a database of biological relations, ontologies and pathways. ResNet 7.0 covers human, mouse and rat proteins. The filters applied included "all shortest paths between selected entities" and "expand pathway". The information received was narrowed down to our protein lists to obtain their relationships. Protein entities belonging to different functional groups were represented as different shapes. 


\section{Statistical analysis}

Data are presented as mean values \pm standard deviation. Positive identification of proteins by MALDI-TOF-TOF was based on a statistically significant Mascot score $(P<0.05)$. For peptides matching multiple members of a protein family, the reported protein is the one with the highest number of peptide matches.

\section{Results}

\section{Analysis of HEp-2 cell proteomes}

We found 974 and 832 protein spots specifically stained by silver nitrate in HEp-2 cell total and enriched nuclear protein extracts, respectively (Figures $2 \mathrm{~B}$ and $2 \mathrm{E}$ and Additional file 1). Major differences were observed between the two HEp-2 cell proteomes, corresponding to quantitative variation for a given protein spot as well as protein spots that were exclusively detected in one of the two protein extracts. In the total protein extract, a large number of protein spots stained with high intensity migrated between $\mathrm{pH} 4.0$ and 7.0 and between 100 and $10 \mathrm{kDa}$. In the enriched nuclear protein extract, a lower number of protein spots was stained with high intensity and migrated between $\mathrm{pH} 5.0$ and 9.0 and, with several exceptions, between 75 and $30 \mathrm{kDa}$.
After protein transfer and colloidal gold staining, we identified $658 \pm 101$ and $535 \pm 66$ protein spots on average per membrane in total and enriched nuclear protein extracts, respectively (data not shown). Again, quantitative and/or qualitative differences were observed between membranes transferred with one or the other of the protein extracts.

\section{IgG reactivities shared between SSc patients}

In the 15 pools of sera from SSc patients, IgG recognised, on average per membrane, $142 \pm 34$ and $155 \pm$ 47 protein spots in HEp-2 cell total and enriched nuclear protein extracts, respectively, with no significant difference between sera pools (data not shown). Overall, 43 and 33 protein spots were recognised by at least $75 \%$ of pools from patients with dcSSc and/or lcSSc in total and enriched nuclear protein extracts, respectively (Additional files 2 and 3). Thus, 14 and 4 proteins were identified by MS from the protein spots recognised by at least $75 \%$ of the 15 pools in total and enriched nuclear protein extracts, respectively (Table 2). A limited number of proteins were recognised by IgG from all pools of patients. All of these latter proteins were also recognised by IgG from HCs. Interestingly, $\alpha$-enolase was recognised by IgG from all pools of

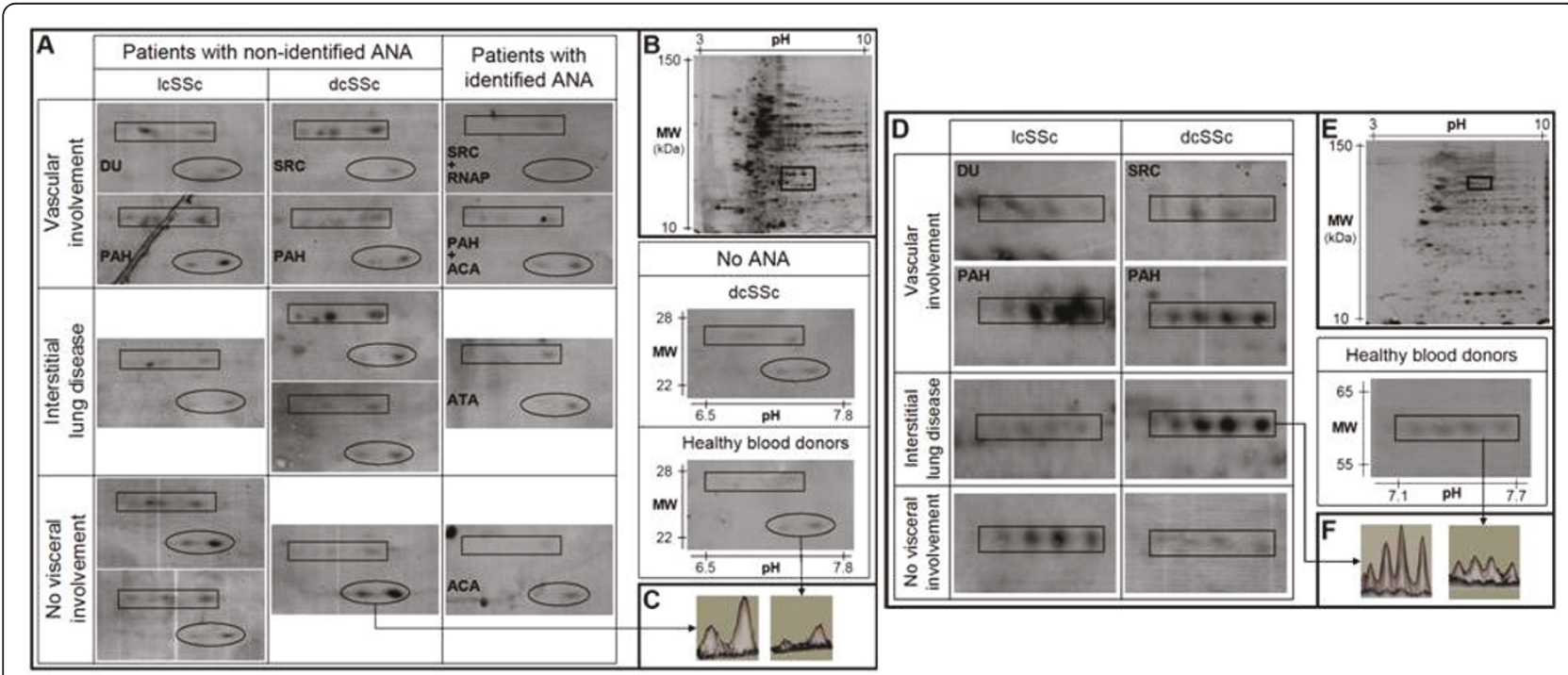

Figure 2 IgG reactivities directed toward triosephosphate isomerase, superoxide dismutase mitochondrial precursor and heterogeneous nuclear ribonucleoprotein L. (A) areas of 2-D membranes with IgG reactivities directed toward triosephosphate isomerase (rectangles) and superoxide dismutase mitochondrial precursor (ovals) in sera from patients with different subsets of SSc and from healthy blood donors in total protein extract. (D) Areas of 2-D membranes with IgG reactivities directed toward heterogeneous nuclear ribonucleoprotein $L$ in sera from SSc patients with unidentified ANA and from healthy blood donors in enriched nuclear protein extract. 2-D silver-stained gel of total (B) and nuclear (E) protein extracts from HEp-2 cells. First dimension (x-axis): pH range from 3 to 10; second dimension: range from 150 to 10 $\mathrm{kDa}$ ( $\mathrm{y}$-axis). The areas delineated by rectangles in $\mathrm{B}(\mathrm{pH} 6.5$ to $7.8 ; 22$ to $28 \mathrm{kDa}$ ) and $\mathrm{D}(\mathrm{pH} 7.1$ to $7.7 ; 55$ to $65 \mathrm{kDa}$ ) correspond to the region of membranes magnified in A and D, respectively. (C and F) 3-D representation of lgG reactivity peaks in a sera pool from three patients (left) and from the 12 healthy blood donors (right). ACA: anticentromere antibody; ANA: antinuclear antibody; ATA: antitopoisomerase I antibody; dcSSc: diffuse cutaneous systemic sclerosis; DU: digital ulcer; ICSSc: limited cutaneous systemic sclerosis; MW: molecular weight; PAH: pulmonary arterial hypertension; RNAP: anti-RNA polymerase III antibody; SRC: scleroderma renal crisis; SSc: systemic sclerosis. 
Table 2 HEp-2 cell proteins recognised by immunoglobulin $\mathrm{G}$ in at least $\mathbf{7 5} \%$ of sera pools from patients $^{\text {a }}$

\begin{tabular}{|c|c|}
\hline Protein & $\begin{array}{l}\text { SwissProt accession } \\
\text { number }\end{array}$ \\
\hline \multicolumn{2}{|l|}{ Total protein extract } \\
\hline Heat shock $70-k D a$ protein $1^{b}$ & $\begin{array}{l}\text { [SwissProt: } \\
\text { HSP71_HUMAN] }\end{array}$ \\
\hline Stress-induced phosphoprotein 1 & $\begin{array}{l}\text { [SwissProt: } \\
\text { STIP1_HUMAN] }\end{array}$ \\
\hline Protein disulfide-isomerase A3 precursor & $\begin{array}{l}\text { [SwissProt: } \\
\text { PDIA3_HUMAN] }\end{array}$ \\
\hline Glial fibrillary acidic protein ${ }^{b}$ & $\begin{array}{l}\text { [SwissProt: } \\
\text { GFAP_HUMAN] }\end{array}$ \\
\hline$\alpha$-enolase ${ }^{b}$ & $\begin{array}{l}\text { [SwissProt: } \\
\text { ENOA_HUMAN] }\end{array}$ \\
\hline $\begin{array}{l}\text { Mannose-6 phosphate receptor-binding } \\
\text { protein } 1\end{array}$ & $\begin{array}{l}\text { [SwissProt: } \\
\text { M6PBP_HUMAN] }\end{array}$ \\
\hline $40 S$ ribosomal protein $S A^{b}$ & $\begin{array}{l}\text { [SwissProt: } \\
\text { RSSA_HUMAN] }\end{array}$ \\
\hline Phosphoglycerate kinase 1 & $\begin{array}{l}\text { [SwissProt: } \\
\text { PGK1_HUMAN] }\end{array}$ \\
\hline Actin, cytoplasmic $1^{\mathrm{b}}$ & $\begin{array}{l}\text { [SwissProt: } \\
\text { ACTB_HUMAN] }\end{array}$ \\
\hline $\begin{array}{l}\text { Glyceraldehyde-3-phosphate } \\
\text { dehydrogenase }\end{array}$ & [SwissProt:G3P_HUMAN] \\
\hline $\begin{array}{l}\text { Heterogeneous nuclear } \\
\text { ribonucleoproteins A2/B1 }\end{array}$ & $\begin{array}{l}\text { [SwissProt: } \\
\text { ROA2_HUMAN] }\end{array}$ \\
\hline Triosephosphate isomerase ${ }^{b}$ & [SwissProt:TPIS_HUMAN] \\
\hline Peroxiredoxin 6 & $\begin{array}{l}\text { [SwissProt: } \\
\text { PRDX6_HUMAN] }\end{array}$ \\
\hline $\begin{array}{l}\text { Superoxide dismutase }[\mathrm{Mn}] \text {, } \\
\text { mitochondrial precursor }{ }^{\mathrm{b}}\end{array}$ & $\begin{array}{l}\text { [SwissProt: } \\
\text { SODM_HUMAN] }\end{array}$ \\
\hline \multicolumn{2}{|l|}{ Enriched nuclear protein extract } \\
\hline $\begin{array}{l}\text { Heterogeneous nuclear } \\
\text { ribonucleoprotein } L^{\mathrm{b}}\end{array}$ & $\begin{array}{l}\text { [SwissProt: } \\
\text { HNRPL_HUMAN] }\end{array}$ \\
\hline Pre-mRNA processing factor 19 & $\begin{array}{l}\text { [SwissProt: } \\
\text { PRP19_HUMAN] }\end{array}$ \\
\hline$\alpha$-enolase $^{\mathrm{b}}$ & $\begin{array}{l}\text { [SwissProt: } \\
\text { ENOA_HUMAN] }\end{array}$ \\
\hline Poly(rC)-binding protein 1 & $\begin{array}{l}\text { [SwissProt: } \\
\text { PCBP1_HUMAN] }\end{array}$ \\
\hline
\end{tabular}

${ }^{a}$ SSc: systemic sclerosis. ${ }^{b} \mathrm{HEp}-2$ cell proteins recognised by all pools of sera from SSc patients with unidentified antinuclear antibodies.

patients in both extracts. Finally, among the spots recognised by IgG from the 10 pools of sera from patients with unidentified ANAs, 15 were specifically recognised by IgG from at least 4 of these 10 pools in total or enriched nuclear protein extracts (Table 3 )

\section{Comparison of IgG reactivities in sera from HCs and SSc patients}

Serum IgG from the pool of 12 HCs recognised $95 \pm 1$ and $108 \pm 3$ protein spots in total and enriched nuclear protein extracts, respectively. In the total protein extract, IgG reactivity for triosephosphate isomerase (TPI) and superoxide dismutase mitochondrial precursor (SOD2) was higher in the majority of pools of SSc patients, especially in those with sera from patients with unidentified ANAs, than in the pool of sera from HCs (Figure 2). Although IgG reactivity was slightly higher for SOD2 in sera from patients without visceral involvement, IgG reactivities did not differ between subgroups of patients for TPI or SOD2. In the enriched nuclear protein extract, IgG reactivity for heterogeneous nuclear ribonucleoprotein L (hnRNP L) was high in several sera pools from SSc patients with unidentified ANAs and low in the pool of sera from HCs (Figure 2). In both total and enriched nuclear protein extracts, IgG reactivity for lamin $\mathrm{A} / \mathrm{C}$ was high in several sera pools from patients with unidentified ANAs (Figure 3). Interestingly, no IgG reactivity for lamin $\mathrm{A} / \mathrm{C}$ was observed in sera pools from $\mathrm{HCs}$ and from patients with identified ANAs or without ANAs. Finally, IgG reactivity for lamin A/C was high in the pool of sera from patients with lcSSc, digital ulcers and unidentified ANAs in both total and enriched nuclear protein extracts (Figures 3A and 3D).

\section{Subset-specific IgG reactivities in sera from patients with unidentified ANAs}

Using both groups of experiments performed with total and enriched nuclear protein extracts, we identified IgG reactivities that were specific for each phenotypic subset of patients with unidentified ANAs. MS identified a number of key target antigens (Table 4). Interestingly, with the exception of one subset, we identified at least one and up to four target antigens recognised by sera pools from each subset of patients with unidentified ANAs, including cofilin 1, peroxiredoxin 2 (PRDX2) and calreticulin (Table 4). One target antigen, eukaryotic translation initiation factor $5 \mathrm{~A}-1$, was identified in both the total and the enriched nuclear protein extracts from patients with the same disease subset.

\section{Biological network analysis of identified autoantibody specificities}

Lists of HEp-2 cell proteins specifically recognised and/or recognised with high intensity by IgG from SSc patients were analysed by using Pathway Studio software. Interestingly, most of these proteins were involved in the transforming growth factor $\beta$ (TGF- $\beta$ ) pathway (Additional file 4). From this network, we wanted to focus on molecules recognised by IgG from SSc patients with unidentified ANAs. This allowed us to depict the signalling network between TGF- $\beta$ and HEp-2 cell proteins identified as major targets of autoantibodies in SSc patients with unidentified ANAs (Figure 4). Thus, the expression of these proteins can be either increased or decreased by TGF- $\beta$. Interestingly, some of these proteins are involved in the pathophysiological process of SSc. 
Table 3 Proteins specifically recognised by IgG from at least four pools of patients with unidentified ANA

\begin{tabular}{|c|c|c|c|c|c|c|c|c|}
\hline $\begin{array}{l}\text { Protein ID } \\
\text { on gel }\end{array}$ & HEp-2 cell protein & $\begin{array}{l}\text { SwissProt } \\
\text { accession } \\
\text { number }\end{array}$ & $\begin{array}{l}\text { MW } \\
\text { th/es }\end{array}$ & $\mathrm{pH}_{\mathrm{i}}$ th/es & $\begin{array}{l}\text { Number of unique } \\
\text { identified peptides }\end{array}$ & $\begin{array}{l}\text { Total } \\
\text { ion } \\
\text { score }\end{array}$ & $\begin{array}{l}\text { Best ion } \\
\text { score }\end{array}$ & $\begin{array}{c}\text { Sequence } \\
\text { coverage (\%) }\end{array}$ \\
\hline 550 & $\begin{array}{l}\text { Far upstream element-binding } \\
\text { protein } 2(\mathrm{~N})\end{array}$ & $\begin{array}{l}\text { [SwissProt: } \\
\text { FUBP2_HUMAN] }\end{array}$ & $73 / 80$ & $6.8 / 7.1$ & $10 / 17$ & 554 & 108 & 37 \\
\hline 553 & $\begin{array}{l}\text { Far upstream element-binding } \\
\text { protein } 2(\mathrm{~N})\end{array}$ & $\begin{array}{l}\text { [SwissProt: } \\
\text { FUBP2_HUMAN] }\end{array}$ & $73 / 79$ & $6.8 / 7.3$ & $11 / 17$ & 864 & 153 & 32 \\
\hline 554 & $\begin{array}{l}\text { Far upstream element-binding } \\
\text { protein } 2(\mathrm{~N})\end{array}$ & $\begin{array}{l}\text { [SwissProt: } \\
\text { FUBP2_HUMAN] }\end{array}$ & $73 / 79$ & $6.8 / 7.5$ & $10 / 17$ & 598 & 105 & 34 \\
\hline 617 & Lamin $A / C(N)$ & $\begin{array}{l}\text { [SwissProt: } \\
\text { LMNA_HUMAN] }\end{array}$ & $74 / 73$ & $6.6 / 7.0$ & $11 / 29$ & 680 & 127 & 50 \\
\hline 762 & RNA-binding protein FUS (N) & $\begin{array}{l}\text { [SwissProt: } \\
\text { FUS_HUMAN] }\end{array}$ & $53 / 61$ & $9.4 / 7.8$ & $2 / 5$ & 64 & 45 & 17 \\
\hline 771 & $\begin{array}{l}\text { Ras GTPase-activating protein- } \\
\text { binding protein } 1(\mathrm{~N})\end{array}$ & $\begin{array}{l}\text { [SwissProt: } \\
\text { G3BP1_HUMAN] }\end{array}$ & $52 / 61$ & $5.4 / 6.0$ & $5 / 12$ & 381 & 131 & 39 \\
\hline 913 & Lamin $A / C(T)$ & $\begin{array}{l}\text { [SwissProt: } \\
\text { LMNA_HUMAN] }\end{array}$ & $74 / 77$ & $6.6 / 7.0$ & $5 / 14$ & 120 & 39 & 28 \\
\hline 914 & Lamin A/C (T) & $\begin{array}{l}\text { [SwissProt: } \\
\text { LMNA_HUMAN] }\end{array}$ & $74 / 77$ & $6.6 / 6.8$ & $7 / 23$ & 121 & 38 & 42 \\
\hline \multirow[t]{2}{*}{921} & RuvB-like 1 (N) & $\begin{array}{l}\text { [SwissProt: } \\
\text { RUVB1_HUMAN] }\end{array}$ & $50 / 50$ & $6.0 / 6.8$ & $8 / 16$ & 591 & 131 & 50 \\
\hline & Protein DEK (N) & $\begin{array}{l}\text { [SwissProt: } \\
\text { DEK_HUMAN] }\end{array}$ & $43 / 50$ & $8.7 / 6.8$ & $2 / 4$ & 162 & 92 & 12 \\
\hline 924 & $\begin{array}{l}\text { Heterogeneous nuclear } \\
\text { ribonucleoprotein H (N) }\end{array}$ & $\begin{array}{l}\text { [SwissProt: } \\
\text { HNRH1_HUMAN] }\end{array}$ & $49 / 49$ & $5.9 / 6.4$ & $8 / 15$ & 440 & 80 & 53 \\
\hline 1132 & $\begin{array}{l}\text { 60-kDa heat shock protein, } \\
\text { mitochondrial precursor }(T)\end{array}$ & $\begin{array}{l}\text { [SwissProt: } \\
\text { CH60_HUMAN] }\end{array}$ & $61 / 61$ & $5.7 / 5.5$ & $7 / 15$ & 176 & 36 & 28 \\
\hline 1191 & $\begin{array}{l}\text { Serine/threonine protein } \\
\text { phosphatase PP1- } \beta \text { catalytic } \\
\text { subunit (N) }\end{array}$ & $\begin{array}{l}\text { [SwissProt: } \\
\text { PP1B_HUMAN] }\end{array}$ & $37 / 34$ & $5.8 / 6.1$ & $2 / 10$ & 62 & 41 & 35 \\
\hline 1629 & Annexin A1 (T) & $\begin{array}{l}\text { [SwissProt: } \\
\text { ANXA1_HUMAN] }\end{array}$ & $39 / 38$ & $6.6 / 6.7$ & $6 / 13$ & 233 & 73 & 50 \\
\hline 2212 & Stathmin $(T)$ & $\begin{array}{l}\text { [SwissProt: } \\
\text { STMN1_HUMAN] }\end{array}$ & $17 / 18$ & $5.8 / 6.2$ & $2 / 6$ & 82 & 51 & 32 \\
\hline 2039 & $\begin{array}{l}\text { Histone-binding protein } \\
\text { RBBP4 (N) }\end{array}$ & $\begin{array}{l}\text { [SwissProt: } \\
\text { RBBP4_HUMAN] }\end{array}$ & $48 / 48$ & $4.7 / 5.1$ & $7 / 10$ & 414 & 103 & 27 \\
\hline
\end{tabular}

${ }^{a}$ ANA: antinuclear antibody; FUS: fused in sarcoma; MW: molecular weight (in kilodaltons); N: proteins recognised in HEp-2 cell-enriched nuclear protein extract; $\mathrm{pH}_{\mathrm{i}}$, intracellular $\mathrm{pH}$; PP1: protein phosphatase 1; SSc: systemic sclerosis; T: proteins recognised in HEp-2 cell total protein extract; th/es: theoretical/estimated.

${ }^{b}$ Number of uniquely identified peptides in tandem mass spectrometry (MS/MS) and mass spectrometry + MS/MS searches.

\section{Discussion}

In the present work, we have identified a number of new target antigens for autoantibodies in SSc patients that are either shared among patients or specific to a given phenotype. For some antigens, including TPI, SOD2, hnRNP $\mathrm{L}$ and lamin $\mathrm{A} / \mathrm{C}$, IgG reactivity was higher in sera pools from patients than in pools from HCs. TPI, a glycolytic enzyme localised in the cytoplasm, is one of the nine proteins specifically identified in whole saliva from patients with dcSSc as compared with HCs [17]. Interestingly, we recently identified another glycolytic enzyme, $\alpha$-enolase, as a target of antifibroblast antibodies in SSc patients, particularly those with ILD and/or ATAs $[18,19]$. SOD2 is a mitochondrial metalloenzyme that catalyses the dismutation of the superoxide anion to hydrogen peroxide and oxygen and protects against reactive oxygen species (ROS). Thus, autoantibodies directed against SOD2 might impair the enzyme function and favour ROS accumulation. This finding could be relevant to the pathogenesis of SSc, because a major increase in ROS level is a hallmark of SSc [20]. Interestingly, Dalpke et al. [21] reported that a hyperimmune serum against SOD2 inhibited the protective effects of SOD2 on endothelial cells exposed to oxidative stress. In addition, downregulation of SOD2 expression was described in osteoarthritis [22], and anti-TPI antibodies have been identified in several autoimmune conditions, including neuropsychiatric systemic lupus erythematosus (SLE) [23], and in osteoarthritis [24].

Lamins $\mathrm{A}$ and $\mathrm{C}$ are both encoded by the LMNA gene and represent major constituents of the inner nuclear membrane. Mutations of this gene have been identified in a number of conditions, including HutchinsonGilford progeria syndrome [25], which represents a 


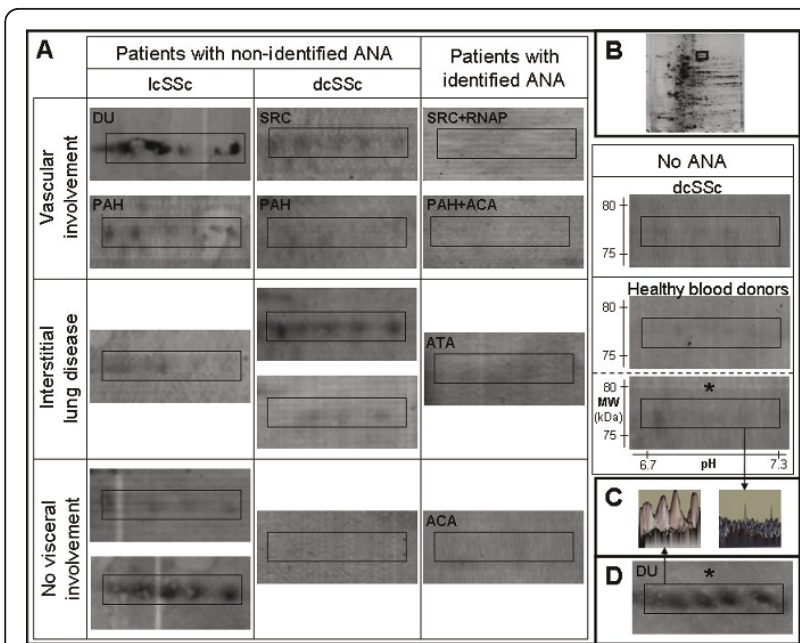

Figure 3 lgG reactivities directed toward lamin A/C. (A) Areas of 2-D membranes with IgG reactivities directed toward lamin $A / C$ in sera from patients with different subsets of SSC and from healthy blood donors in total or nuclear $\left(^{*}\right)$ protein extracts from HEp-2 cells. (B) 2-D silver-stained gel of HEp-2 cell total protein extract. The areas delineated by rectangles correspond to the region of membranes magnified in $\mathrm{A}$ ( $\mathrm{pH} 6.7$ to $7.3 ; 75$ to $80 \mathrm{kDa}$ ). (C) 3-D representation of IgG reactivity peaks in a sera pool from three patients (left) and from the 12 healthy blood donors (right). (D) IgG reactivities directed toward lamin $A / C$ in enriched nuclear protein extract in the sera pool from patients with ICSSC, DU and unidentified ANA. ACA: anticentromere antibody; ANA: antinuclear antibody; ATA: antitopoisomerase I antibody; dcSSc: diffuse cutaneous systemic sclerosis; DU: digital ulcer; IcSSc: limited cutaneous systemic sclerosis; MW: molecular weight; PAH: pulmonary arterial hypertension; RNAP: anti-RNA polymerase III antibody; SRC: scleroderma renal crisis; SSc: systemic sclerosis.

major differential diagnosis of juvenile SSc. The most frequent mutation responsible for progeria creates a truncated progeria mutant lamin A (progerin), which accumulates within the nuclei of human vascular cells and may be directly responsible for vascular involvement in progeria [26]. The identification of lamin as a major target of autoantibodies in SSc patients precludes the potential role of modified and/or dysfunctional lamin and/or antilamin autoantibodies in the pathogenesis of SSc. Antilamin antibodies were found in sera from patients with SLE [27] and antiphospholipid syndrome [28] as well as in a patient with linear morphea [29].

HnRNP L is a nuclear protein associated with hnRNP complexes and takes part in the processing of pre-mRNA. Anti-hnRNP L antibodies were identified in a small cohort of SSc patients in association with anti-hnRNP A/B antibodies [30]. HnRNP L was also identified as a target of autoantibodies in New Zealand White $\times$ BXSB mice with SLE and antiphospholipid syndrome [31].

Our analysis revealed that PRDX2, cofilin 1 and calreticulin were specifically recognised by IgG from phenotypic subsets of patients with unidentified ANAs. Other target antigens listed in Table 4 might also be relevant and should be tested in further work. PRDX2 is a peroxidase that eliminates endogenous ROS produced in response to growth factors such as platelet-derived growth factor (PDGF). PRDX2 influences oxidative and heat stress resistance [32] and inhibits PDGF signalling and vascular remodelling [33]. Interestingly, PRDX2 has recently been identified as a target of anti-endothelial cell antibodies in systemic vasculitis [34].

Cofilin 1 is a regulator of actin depolymerisation. Cofilin is a major effector of nicotinamide adenine dinucleotide phosphate (NADPH) oxidase 1-mediated migration, and NADPH oxidase 1 plays a critical role in neointima formation by mediating vascular smooth muscle cell migration, proliferation and extracellular matrix production [35]. Moreover, regulation of the phosphorylation state of cofilin controls PDGF-induced migration of human aortic smooth muscle cells [36]. Anti-cofilin 1 antibodies have been detected in a few patients with rheumatoid arthritis, SLE or polymyositis and/or dermatomyositis [37].

Calreticulin is an endoplasmic reticulum chaperone and an intracellular calcium-binding protein and thus is involved in signal transduction pathways. In apoptotic cells, calreticulin is translocated to the cell surface, conferring immunogenicity of cell death [38]. Calreticulin has been described as a potential cell surface receptor involved in cell penetration of anti-DNA antibodies in patients with SLE [39]. Anticalreticulin antibodies have been reported in patients with celiac disease and SLE $[40,41]$.

Interestingly, we determined that several autoantigens recognised by IgG from SSc patients were involved in the TGF- $\beta$ pathway. In the pathophysiology of SSc, fibroblast proliferation and accumulation of extracellular matrix result from uncontrolled activation of the TGF- $\beta$ pathway and from excess synthesis of connective tissue growth factor, PDGF, proinflammatory cytokines and ROS [3]. Thus, increased expression and/or modified structure or fragmentation in the presence of ROS of a number of proteins involved in the TGF- $\beta$ pathway could trigger specific immune responses in these patients. Casciola-Rosen et al. [42] reported on the sensitivity of scleroderma antigens to ROS-induced fragmentation in this setting, possibly through ischemiareperfusion injury as the potential initiator of the autoimmune process in SSc.

The combined use of 2-DE and immunoblotting offers an interesting approach to identifying target antigens of autoantibodies [10,13]. We used HEp-2 cells as sources of autoantigens because these cells are routinely used to detect ANAs. Although not directly relevant to the 
Table 4 Proteins specifically recognised by IgG from patients with the same phenotype and expressing unidentified ANA $^{\mathrm{a}}$

\begin{tabular}{|c|c|c|c|c|c|c|c|c|c|}
\hline $\begin{array}{l}\text { Subset of } \\
\text { patients }\end{array}$ & $\begin{array}{l}\text { Protein } \\
\text { ID on gel }\end{array}$ & HEp-2 cell protein & $\begin{array}{l}\text { SwissProt } \\
\text { accession } \\
\text { number }\end{array}$ & MW th/es & $\mathrm{pH}_{\mathrm{i}}$ th/es & $\begin{array}{l}\text { Number of } \\
\text { unique } \\
\text { identified } \\
\text { peptides }^{\#}\end{array}$ & $\begin{array}{l}\text { Total } \\
\text { ion } \\
\text { score }\end{array}$ & $\begin{array}{l}\text { Best } \\
\text { ion } \\
\text { score }\end{array}$ & $\begin{array}{l}\text { Sequence } \\
\text { coverage } \\
(\%)\end{array}$ \\
\hline \multirow[t]{4}{*}{ dcSSc/SRC } & 1100 & Calreticulin precursor $(\mathrm{T})$ & $\begin{array}{l}\text { [SwissProt: } \\
\text { CALR_HUMAN] }\end{array}$ & $48 / 63$ & $4.3 / 4.4$ & $5 / 16$ & 136 & 36 & 25 \\
\hline & 1420 & $\begin{array}{l}\text { Pre-mRNA splicing factor } \\
\text { SPF27 (N) }\end{array}$ & $\begin{array}{l}\text { [SwissProt: } \\
\text { SPF27_HUMAN] }\end{array}$ & $26 / 25$ & $5.5 / 5.9$ & $6 / 10$ & 377 & 115 & 47 \\
\hline & 1636 & $\begin{array}{l}\text { Eukaryotic translation } \\
\text { initiation factor } 5 \mathrm{~A}-1(\mathrm{~N})\end{array}$ & $\begin{array}{l}\text { [SwissProt: } \\
\text { IF5A1_HUMAN] }\end{array}$ & $17 / 16$ & $5.1 / 5.7$ & $3 / 3$ & 163 & 101 & 33 \\
\hline & 2249 & $\begin{array}{l}\text { Eukaryotic translation } \\
\text { initiation factor } 5 \mathrm{~A}-1(\mathrm{~T})\end{array}$ & $\begin{array}{l}\text { [SwissProt: } \\
\text { IF5A1_HUMAN] }\end{array}$ & $17 / 17$ & $5.1 / 5.6$ & $2 / 5$ & 80 & 69 & 22 \\
\hline dcSSc/PAH & - & - & - & - & - & & & & \\
\hline \multirow[t]{3}{*}{ dcSSc/ILD } & 589 & $\begin{array}{l}\text { Probable ATP-dependent } \\
\text { RNA helicase DDX17 (N) }\end{array}$ & $\begin{array}{l}\text { [SwissProt: } \\
\text { DDX17_HUMAN] }\end{array}$ & $72 / 76$ & 8.8/8.0 & $8 / 20$ & 207 & 35 & 36 \\
\hline & 1101 & Poly(rC)-binding protein $2(\mathrm{~N})$ & $\begin{array}{l}\text { [SwissProt: } \\
\text { PCBP2_HUMAN] }\end{array}$ & $39 / 39$ & $6.3 / 6.9$ & $5 / 10$ & 132 & 56 & 41 \\
\hline & 1151 & $\begin{array}{l}\text { Serine/threonine protein } \\
\text { phosphatase PP1- } \alpha \text { catalytic } \\
\text { subunit (N) }\end{array}$ & $\begin{array}{l}\text { [SwissProt: } \\
\text { PP1A_HUMAN] }\end{array}$ & $37 / 35$ & $5.9 / 6.5$ & 10/17 & 476 & 114 & 61 \\
\hline \multirow[t]{2}{*}{ dcSSc* } & 1417 & $\begin{array}{l}\text { DNA-directed RNA } \\
\text { polymerases I, II and III, } \\
\text { subunit RPABC1 (N) }\end{array}$ & $\begin{array}{l}\text { [SwissProt: } \\
\text { RPAB1_HUMAN] }\end{array}$ & $25 / 25$ & $5.7 / 6.3$ & $2 / 4$ & 150 & 117 & 21 \\
\hline & 2163 & Cofilin $1(T)$ & $\begin{array}{l}\text { [SwissProt: } \\
\text { COF1_HUMAN] }\end{array}$ & 19/19 & $8.2 / 9.5$ & $3 / 7$ & 134 & 72 & 54 \\
\hline IcSSc/DU & 2317 & Histone H2A type 1-J (T) & $\begin{array}{l}\text { [SwissProt: } \\
\text { H2A1J_HUMAN] }\end{array}$ & $14 / 16$ & $10.9 / 6.1$ & $2 / 3$ & 37 & 20 & 27 \\
\hline \multirow[t]{3}{*}{ ICSSC/PAH } & 882 & $\begin{array}{l}\text { Telomeric repeat binding } \\
\text { factor } 2 \text {-interacting protein } 1 \\
\text { (N) }\end{array}$ & $\begin{array}{l}\text { [SwissProt: } \\
\text { TE2IP_HUMAN] }\end{array}$ & $44 / 52$ & $4.6 / 4.9$ & $9 / 15$ & 286 & 71 & 48 \\
\hline & 1119 & $\begin{array}{l}\text { Heterogeneous nuclear } \\
\text { ribonucleoprotein A/B (N) }\end{array}$ & $\begin{array}{l}\text { [SwissProt: } \\
\text { ROAA_HUMAN] }\end{array}$ & $36 / 38$ & $8.2 / 6.5$ & $3 / 5$ & 55 & 27 & 15 \\
\hline & 2079 & Peroxiredoxin 2 (T) & $\begin{array}{l}\text { [SwissProt: } \\
\text { PRDX2_HUMAN] }\end{array}$ & $22 / 23$ & $5.7 / 6.0$ & $5 / 7$ & 143 & 40 & 26 \\
\hline \multirow[t]{2}{*}{ ICSSc/ILD } & 901 & $\begin{array}{l}\text { 78-kDa glucose-regulated } \\
\text { protein precursor }(T)\end{array}$ & $\begin{array}{l}\text { [SwissProt: } \\
\text { GRP78_HUMAN] }\end{array}$ & $72 / 76$ & $5.1 / 5.4$ & $13 / 29$ & 711 & 121 & 28 \\
\hline & 2063 & $\begin{array}{l}\text { ATP-dependent DNA helicase } \\
\text { 2, subunit } 1(\mathrm{~N})\end{array}$ & $\begin{array}{l}\text { [SwissProt: } \\
\text { KU70_HUMAN] }\end{array}$ & $70 / 70$ & $6.2 / 6.9$ & $3 / 14$ & 89 & 45 & 29 \\
\hline \multirow[t]{3}{*}{$\operatorname{ICSSC} c^{*}$} & 820 & $\begin{array}{l}\text { U4/U6 small nuclear } \\
\text { ribonucleoprotein Prp31 (N) }\end{array}$ & $\begin{array}{l}\text { [SwissProt: } \\
\text { PRP31_HUMAN] }\end{array}$ & $55 / 57$ & $5.6 / 6.4$ & $3 / 7$ & 112 & 64 & 16 \\
\hline & 1478 & Calumenin precursor $(\mathrm{T})$ & $\begin{array}{l}\text { [SwissProt: } \\
\text { CALU_HUMAN] }\end{array}$ & $37 / 44$ & $4.5 / 4.6$ & $3 / 7$ & 82 & 39 & 29 \\
\hline & 1895 & Tumour protein D54 (T) & $\begin{array}{l}\text { [SwissProt: } \\
\text { TPD54_HUMAN] }\end{array}$ & $22 / 29$ & $5.3 / 5.6$ & $1 / 3$ & 47 & 47 & 23 \\
\hline
\end{tabular}

${ }^{a}$ ANA: antinuclear antibody; dcSSc: diffuse cutaneous systemic sclerosis; DU: digital ulcer; ILD: interstitial lung disease; IcSSc: limited cutaneous systemic sclerosis; MW: molecular weight (in kilodaltons); N: proteins recognised in HEp-2 cell-enriched nuclear protein extract; PAH: pulmonary arterial hypertension; SRC: scleroderma renal crisis; SSc: systemic sclerosis; T: proteins recognised in HEp-2 cell total protein extract; th/es: theoretical/estimated. ${ }^{b} \mathrm{Number}$ of unique identified peptides in MS/MS and in MS+MS/MS searches. 'Without visceral involvement.

pathogenesis of SSc, we thought it more appropriate to use these cells as sources of autoantigens because we were looking for additional targets to ANAs. Additional validation studies with sera from patients with other connective tissue diseases are necessary. In addition, 2$\mathrm{DE}$ and immunoblotting were not adapted to test a large number of sera, and thus further experiments using ELISA with recombinant proteins are necessary, which will allow for validation of the target antigens and screening of a large number of patients.

However, our work has several additional limitations. Less than 1,000 protein spots were stained in the 


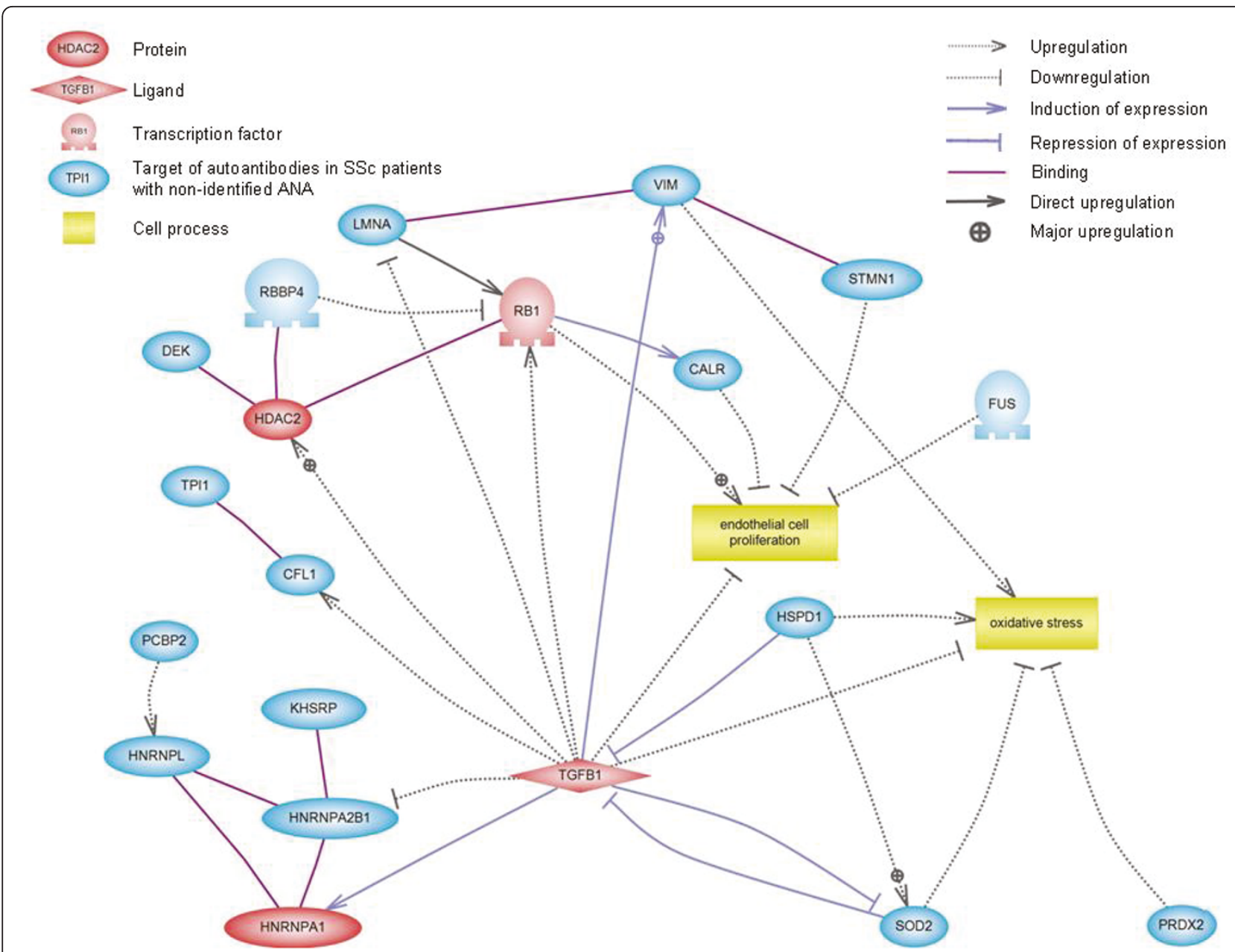

Figure 4 Signalling network of proteins identified as major targets of autoantibodies in patients with unidentified ANA. This schematic representation, created by using Pathway Studio software, shows the connectivity between TGF- $\beta$ and HEp-2 cell proteins identified as major targets of autoantibodies in SSC patients with unidentified ANA. Protein entities belonging to different functional groups are represented as different shapes. ANA: antinuclear antibody; CALR: calreticulin; CFL1: cofilin 1; FUS: fused in sarcoma; HDAC2: histone deacetylase 2; HNRNPA1: heterogeneous nuclear ribonucleoprotein A1; HNRNPA2B1: heterogeneous nuclear ribonucleoprotein A2/B1; HNRNPL: heterogeneous nuclear ribonucleoprotein L; HSPD1: heat shock 60-kDa protein 1; KHSRP: KH-type splicing regulatory protein (far upstream element-binding protein 2); LMNA: lamin A/C; PCBP2: poly(rC)-binding protein 2; PRDX2: peroxiredoxin 2; RB1: retinoblastoma-associated protein; RBBP4: retinoblastomabinding protein 4; SOD2: superoxide dismutase 2, mitochondrial; SSc: systemic sclerosis; STMN1: stathmin 1; TGFB1: transforming growth factor $\beta 1$; TPI1: triosephosphate isomerase 1; VIM: vimentin.

reference gel of the total protein extract. Therefore, a number of proteins were probably lost at each step of the technique, depending on their charge, molecular weight, subcellular localisation and/or abundance in the cell. Topoisomerase II is not detected by traditional methods of 2-DE [43], and we failed to identify topoisomerase I or centromeric protein $B$ as target antigens of IgG autoantibodies, whereas these antigens are easily detected in 1-D gels $[6,44,45]$. Anti-topoisomerase I and anti-RNA polymerase III antibodies preferentially recognise a discontinuous or conformational epitope that may not be detected in 2-D gels $[46,47]$. As expected, none of the identified antigens was located at the cell surface, since protein extraction for 2-DE does not allow the identification of membrane proteins.

\section{Conclusions}

We have identified new target autoantigens in SSc patients, a number of which are involved in the TGF- $\beta$ pathway. Although these data must be confirmed by other groups and in large cohorts of patients with SSc or other connective tissue diseases, these new autoantibody specificities could represent major advances in the diagnosis and prognosis of patients with SSc. 


\section{Additional material}

Additional file 1: Supplemental Figure S1. HEp-2 cell proteomes. (A)

2-D silver-stained gel of total protein extract and (C) enriched nuclear protein extract. First dimension ( $x$-axis): $\mathrm{pH}$ range 3 to 10; second dimension: range from 150 to $10 \mathrm{kDa}$ (y-axis). $\mathrm{B}$ and $\mathrm{D}$ are magnifications of the delineated zones in $A$ and $C$, respectively. Proteins of interest are indicated by the protein ID provided by ImageMaster 2D Platinum 6.0 software or their SwissProt accession numbers (see Tables 2, 3 and 4 for the names of these proteins). Protein spots delineated by rectangles are different isoforms of the same protein.

Additional file 2: Supplemental Table S1. Proteins recognised by immunoglobulin $\mathrm{G}(\mathrm{IgG})$ in at least $75 \%$ of pools of patients with diffuse cutaneous systemic sclerosis (dcSSc) and/or limited cutaneous systemic sclerosis (ICSSC) in HEp-2 cell total protein extract.

Additional file 3: Supplemental Table S2. Proteins recognised by immunoglobulin $\mathrm{G}$ in at least $75 \%$ of pools of patients with dcSSC and/ or ICSSC in HEp-2 cell-enriched nuclear protein extract.

Additional file 4: Supplemental Figure S2. Signalling network of HEp-2 cell proteins specifically recognised and/or recognised with high intensity by IgG from SSc patients. This schematic

representation, created by using Pathway Studio software, shows the connectivity between IgG target antigens and TGF- $\beta$. Protein entities belonging to different functional groups are represented as different shapes. CALR: calreticulin; CFL1: cofilin 1; DEK: protein DEK; ENO1: enolase $1 \alpha$; FUS: fused in sarcoma; HDAC1: histone deacetylase 1; HDAC2: histone deacetylase 2; HNRNPA1: heterogeneous nuclear ribonucleoprotein A1; HNRNPA2B1: heterogeneous nuclear ribonucleoprotein A2/B1; HNRNPH1: heterogeneous nuclear ribonucleoprotein $\mathrm{H} 1$; HNRNPK: heterogeneous nuclear ribonucleoprotein K; HNRNPL: heterogeneous nuclear ribonucleoprotein L; HSPD1: heat shock 60-KDa protein 1; KHSRP: KH-type splicing regulatory protein (far upstream element-binding protein 2); LMNA: Iamin A/C; POLR2A: polymerase (RNA) II (DNA-directed) polypeptide A; POLR2E: polymerase (RNA) II (DNA-directed) polypeptide E; PRDX2: peroxiredoxin 2; RBBP4: retinoblastoma-binding protein 4; RUVBL1: RuvB-like 1; SOD2: superoxide dismutase 2, mitochondrial; SSc: systemic sclerosis; STMN1: stathmin 1; TBP: TATA box-binding protein; TGFB1: transforming growth factor $\beta 1$; TOP1: topoisomerase (DNA) I; TPI1: triosephosphate isomerase 1; VIM: vimentin.

\begin{abstract}
Abbreviations
2-DE: two-dimensional electrophoresis; ACA: anti-centromere antibody; ANA: antinuclear antibodies; ATA: anti-topoisomerase I antibody; dcSSc: diffuse cutaneous systemic sclerosis; EDTA: ethylenediaminetetraacetic acid; EGTA: ethyleneglycoltetraacetic acid; HC: healthy controls; hnRNP L: heterogeneous nuclear ribonucleoprotein L; ILD: interstitial lung disease; ICSSc: limited cutaneous systemic sclerosis; MALDI: matrix-assisted laser desorption/ ionization; MS: mass spectrometry; MS/MS: tandem mass spectrometry; $\mathrm{PAH}$ : pulmonary arterial hypertension; PDGF: platelet-derived growth factor; PRDX2: peroxiredoxin 2; PVDF: polyvinylidene difluoride; ROS: reactive oxygen species; SLE: systemic lupus erythematosus; SOD2: superoxide dismutase mitochondrial precursor; SRC: scleroderma renal crisis; SSc: systemic sclerosis; TGF: transforming growth factor; TOF: time of flight; TPI: triosephosphate isomerase.
\end{abstract}

\section{Acknowledgements}

GB received financial support from Avenir Mutualiste des Professions Libérales \& Indépendantes (AMPLI), the Société Nationale Française de Médecine Interne, the Fonds d'Etudes et de Recherche du Corps Médical des hôpitaux de Paris and the Direction Régionale des Affaires Sanitaires et Sociales d'lle-de-France. HD received financial support from AMPLI and Association pour la Recherche en Médecine Interne et en Immunologie Clinique (ARMIIC). MCT received a grant from Pfizer and from the Direction de la Recherche Clinique from the Assistance Publique-Hôpitaux de Paris (Programme Hospitalier de Recherche Clinique National: Auto-Hypertension Artérielle Pulmonaire (Auto-HTAP). We thank Pfizer and the Direction de la
Recherche Clinique from the Assistance Publique-Hôpitaux de Paris for supporting Contrat d'Investigation et de Recherche Clinique 05066, HTAP-lg. We also thank the Association des Sclérodermiques de France, the Groupe Français de Recherche sur la Sclérodermie and the Unité de Recherche Clinique Cochin-Necker.

\section{Author details}

${ }^{1}$ Institut Cochin, Université Paris Descartes, CNRS UMR 8104, 8 rue Méchain, F-75014 Paris, France. ${ }^{2}$ INSERM U1016, 8 rue Méchain, F-75014 Paris, France. ${ }^{3}$ Institut Cochin, Plate-forme Protéomique de I'Université Paris Descartes, CNRS UMR 8104, 22 rue Méchain, F-75014 Paris, France. ${ }^{4}$ Etablissement Français du Sang, hôpital Saint-Vincent de Paul, Assistance PubliqueHôpitaux de Paris, 82 avenue Denfert-Rochereau, F-75674 Paris Cedex 14, France. ${ }^{5}$ Université Paris Descartes, Faculté de Médecine, pôle de Médecine Interne et Centre de référence pour les vascularites nécrosantes et la sclérodermie systémique, hôpital Cochin, Assistance Publique-Hôpitaux de Paris, 27 rue du Faubourg Saint-Jacques, F-75679 Paris Cedex 14, France.

\section{Authors' contributions}

GB participated in study design, performed most of the experiments and drafted the manuscript. HD contributed to the experiments and revised the manuscript. MCT contributed to the study design and the interpretation of data and revised the manuscript. CB and LC performed mass spectrometry experiments and revised the manuscript. CF performed Pathway Studio analysis and revised the manuscript. GW supervised the recruitment of healthy blood donors and revised the manuscript. LG supervised the recruitment of patients with systemic sclerosis and revised the manuscript. LM directed the study design, supervised the recruitment of patients with systemic sclerosis, contributed to the interpretation of data and drafted the manuscript. All authors read and approved the final manuscript.

\section{Competing interests}

The authors declare that they have no competing interests.

Received: 7 February 2011 Revised: 13 April 2011

Accepted: 13 May 2011 Published: 13 May 2011

\section{References}

1. Tamby MC, Chanseaud Y, Guillevin L, Mouthon L: New insights into the pathogenesis of systemic sclerosis. Autoimmun Rev 2003, 2:152-157.

2. Steen VD: Autoantibodies in systemic sclerosis. Semin Arthritis Rheum 2005, 35:35-42.

3. Gabrielli A, Avvedimento EV, Krieg T: Scleroderma. N Engl J Med 2009 , 360:1989-2003.

4. Chizzolini C, Raschi E, Rezzonico R, Testoni C, Mallone R, Gabrielli A, Facchini A, Del Papa N, Borghi MO, Dayer JM, Meroni PL: Autoantibodies to fibroblasts induce a proadhesive and proinflammatory fibroblast phenotype in patients with systemic sclerosis. Arthritis Rheum 2002, 46:1602-1613.

5. Baroni SS, Santillo M, Bevilacqua F, Luchetti M, Spadoni T, Mancini M, Fraticelli P, Sambo P, Funaro A, Kazlauskas A, Avvedimento EV, Gabrielli A: Stimulatory autoantibodies to the PDGF receptor in systemic sclerosis. N Engl J Med 2006, 354:2667-2676.

6. Tamby MC, Servettaz A, Tamas N, Reinbolt J, Caux F, Meyer O, Allanore Y, Kahan A, Guillevin L, Mouthon L: IgG from patients with systemic sclerosis bind to DNA antitopoisomerase 1 in normal human fibroblasts extracts. Biologics 2008, 2:583-591.

7. Ihn H, Sato S, Fujimoto M, Igarashi A, Yazawa N, Kubo M, Kikuchi K, Takehara K, Tamaki K: Characterization of autoantibodies to endothelial cells in systemic sclerosis (SSc): association with pulmonary fibrosis. Clin Exp Immunol 2000, 119:203-209.

8. García de la Peña-Lefebvre P, Chanseaud Y, Tamby MC, Reinbolt J, Batteux F, Allanore Y, Kahan A, Meyer O, Benveniste O, Boyer O, Guillevin L, Boissier MC, Mouthon L: IgG reactivity with a $100-\mathrm{kDa}$ tissue and endothelial cell antigen identified as topoisomerase 1 distinguishes between limited and diffuse systemic sclerosis patients. Clin Immunol 2004, 111:241-251.

9. Mihai C, Tervaert JW: Anti-endothelial cell antibodies in systemic sclerosis. Ann Rheum Dis 2010, 69:319-324.

10. Terrier B, Tamby MC, Camoin L, Guilpain P, Broussard C, Bussone G, Yaici A, Hotellier F, Simonneau G, Guillevin L, Humbert M, Mouthon L: 
Identification of target antigens of antifibroblast antibodies in pulmonary arterial hypertension. Am J Respir Crit Care Med 2008, 177:1128-1134

11. Servettaz A, Guilpain P, Camoin L, Mayeux P, Broussard C, Tamby MC, Tamas N, Kaveri SV, Guillevin L, Mouthon L: Identification of target antigens of antiendothelial cell antibodies in healthy individuals: a proteomic approach. Proteomics 2008, 8:1000-1008.

12. Bradford MM: A rapid and sensitive method for the quantitation of microgram quantities of protein utilizing the principle of protein-dye binding. Anal Biochem 1976, 72:248-254

13. Bussone G, Dib H, Dimitrov JD, Camoin L, Broussard C, Tamas N, Guillevin L, Kaveri SV, Mouthon L: Identification of target antigens of self-reactive lgG in intravenous immunoglobulin preparations. Proteomics 2009, 9:2253-2262

14. Guilpain P, Servettaz A, Tamby MC, Chanseaud Y, Tamas N, Garcia de la Pena-Lefebvre P, Broussard C, Guillevin L, Camoin L, Mouthon L: A combined SDS-PAGE and proteomics approach to identify target autoantigens in healthy individuals and patients with autoimmune diseases. Ann N Y Acad Sci 2007, 1109:538-549.

15. ExPASy Proteomics Server. [http://www.expasy.org].

16. Ariadne Pathway Studio. [http://www.ariadnegenomics.com/products/ pathway-studio/]

17. Giusti L, Bazzichi L, Baldini C, Ciregia F, Mascia G, Giannaccini G, Del Rosso M, Bombardieri S, Lucacchini A: Specific proteins identified in whole saliva from patients with diffuse systemic sclerosis. J Rheumatol 2007, 34:2063-2069.

18. Terrier B, Tamby MC, Camoin L, Guilpain P, Berezne A, Tamas N, Broussard C, Hotellier F, Humbert M, Simonneau G, Guillevin L, Mouthon L: Antifibroblast antibodies from systemic sclerosis patients bind to aenolase and are associated with interstitial lung disease. Ann Rheum Dis 2010, 69:428-433.

19. Bussone $G$, Mouthon L: Interstitial lung disease in systemic sclerosis. Autoimmun Rev 2011, 10:248-255

20. Svegliati $S$, Cancello $R$, Sambo $P$, Luchetti M, Paroncini P, Orlandini G Discepoli G, Paterno R, Santillo M, Cuozzo C, Cassano S, Avvedimento EV, Gabrielli A: Platelet-derived growth factor and reactive oxygen species (ROS) regulate Ras protein levels in primary human fibroblasts via ERK1/ 2: amplification of ROS and Ras in systemic sclerosis fibroblasts. J Biol Chem 2005, 280:36474-36482.

21. Dalpke $A H$, Thomssen $R$, Ritter $K$ : Oxidative injury to endothelial cells due to Epstein-Barr virus-induced autoantibodies against manganese superoxide dismutase. J Med Virol 2003, 71:408-416.

22. Scott JL, Gabrielides C, Davidson RK, Swingler TE, Clark IM, Wallis GA, BootHandford RP, Kirkwood TB, Taylor RW, Young DA: Superoxide dismutase downregulation in osteoarthritis progression and end-stage disease. Ann Rheum Dis 2010, 69:1502-1510.

23. Lefranc $D$, Launay $D$, Dubucquoi $S$, de Seze J, Dussart $P$, Vermersch $M$, Hachulla E, Hatron PY, Vermersch P, Mouthon L, Prin L: Characterization of discriminant human brain antigenic targets in neuropsychiatric systemic lupus erythematosus using an immunoproteomic approach. Arthritis Rheum 2007, 56:3420-3432

24. Xiang $Y$, Sekine $T$, Nakamura $H$, Imajoh-Ohmi S, Fukuda H, Nishioka K Kato T: Proteomic surveillance of autoimmunity in osteoarthritis: identification of triosephosphate isomerase as an autoantigen in patients with osteoarthritis. Arthritis Rheum 2004, 50:1511-1521.

25. Eriksson M, Brown WT, Gordon LB, Glynn MW, Singer J, Scott L, Erdos MR, Robbins CM, Moses TY, Berglund P, Dutra A, Pak E, Durkin S, Csoka AB, Boehnke M, Glover TW, Collins FS: Recurrent de novo point mutations in lamin A cause Hutchinson-Gilford progeria syndrome. Nature 2003, 423:293-298

26. McClintock D, Gordon LB, Djabali K: Hutchinson-Gilford progeria mutant lamin A primarily targets human vascular cells as detected by an anti-Lamin A G608G antibody. Proc Natl Acad Sci USA 2006, 103:2154-2159.

27. Reeves WH, Chaudhary N, Salerno A, Blobel G: Lamin B autoantibodies in sera of certain patients with systemic lupus erythematosus. J Exp Med 1987, 165:750-762
28. Senecal JL, Rauch J, Grodzicky T, Raynauld JP, Uthman I, Nava A Guimond M, Raymond Y: Strong association of autoantibodies to human nuclear lamin B1 with lupus anticoagulant antibodies in systemic lupus erythematosus. Arthritis Rheum 1999, 42:1347-1353.

29. McKeon FD, Tuffanelli DL, Fukuyama K, Kirschner MW: Autoimmune response directed against conserved determinants of nuclear envelope proteins in a patient with linear scleroderma. Proc Natl Acad Sci USA 1983, 80:4374-4378.

30. Siapka S, Patrinou-Georgoula M, Vlachoyiannopoulos PG, Guialis A: Multiple specificities of autoantibodies against hnRNP A/B proteins in systemic rheumatic diseases and hnRNP $L$ as an associated novel autoantigen. Autoimmunity 2007, 40:223-233.

31. Thébault S, Gilbert D, Hubert M, Drouot L, Machour N, Lange C, Charlionet $\mathrm{R}$, Tron F: Orderly pattern of development of the autoantibody response in (New Zealand White $\times \mathrm{BXSB} \mathrm{F}_{1}$ lupus mice: characterization of target antigens and antigen spreading by two-dimensional gel electrophoresis and mass spectrometry. J Immunol 2002, 169:4046-4053.

32. Olahova M, Taylor SR, Khazaipoul S, Wang J, Morgan BA, Matsumoto K, Blackwell TK, Veal EA: A redox-sensitive peroxiredoxin that is important for longevity has tissue- and stress-specific roles in stress resistance. Proc Natl Acad Sci USA 2008, 105:19839-19844.

33. Choi MH, Lee IK, Kim GW, Kim BU, Han YH, Yu DY, Park HS, Kim KY, Lee JS, Choi C, Bae YS, Lee BI, Rhee SG, Kang SW: Regulation of PDGF signalling and vascular remodelling by peroxiredoxin II. Nature 2005, 435:347-353.

34. Karasawa R, Kurokawa MS, Yudoh K, Masuko K, Ozaki S, Kato T: Peroxiredoxin 2 is a novel autoantigen for anti-endothelial cell antibodies in systemic vasculitis. Clin Exp Immunol 2010, 161:459-470.

35. Lee MY, San Martin A, Mehta PK, Dikalova AE, Garrido AM, Datla SR, Lyons E, Krause KH, Banfi B, Lambeth JD, Lassègue B, Griendling KK: Mechanisms of vascular smooth muscle NADPH oxidase 1 (Nox1) contribution to injury-induced neointimal formation. Arterioscler Thromb Vasc Biol 2009, 29:480-487.

36. San Martín A, Lee MY, Williams HC, Mizuno K, Lassègue B, Griendling KK: Dual regulation of cofilin activity by LIM kinase and Slingshot-1L phosphatase controls platelet-derived growth factor-induced migration of human aortic smooth muscle cells. Circ Res 2008, 102:432-438.

37. Ooka S, Nakano H, Matsuda T, Okamoto K, Suematsu N, Kurokawa MS, Ohtani-Kaneko R, Masuko K, Ozaki S, Kato T: Proteomic surveillance of autoantigens in patients with Behçet's disease by a proteomic approach. Microbiol Immunol 2010, 54:354-361.

38. Obeid M, Tesniere A, Ghiringhelli F, Fimia GM, Apetoh L, Perfettini $J$, Castedo M, Mignot G, Panaretakis T, Casares N, Métivier D, Larochette N, van Endert P, Ciccosanti F, Piacentini M, Zitvogel L, Kroemer G: Calreticulin exposure dictates the immunogenicity of cancer cell death. Nat Med 2007, 13:54-61.

39. Seddiki N, Nato F, Lafaye P, Amoura Z, Piette JC, Mazie JC: Calreticulin, a potential cell surface receptor involved in cell penetration of anti-DNA antibodies. J Immunol 2001, 166:6423-6429.

40. Tuckova L, Karska K, Walters JR, Michalak M, Rossmann P, Krupickova S, Verdu EF, Saalman R, Hanson LA, Tlaskalova-Hogenova H: Anti-gliadin antibodies in patients with celiac disease cross-react with enterocytes and human calreticulin. Clin Immunol Immunopathol 1997, 85:289-296.

41. van den Berg RH, Siegert CE, Faber-Krol MC, Huizinga TW, van Es LA, Daha MR: Anti-C1q receptor/calreticulin autoantibodies in patients with systemic lupus erythematosus (SLE). Clin Exp Immunol 1998, 111:359-364.

42. Casciola-Rosen L, Wigley F, Rosen A: Scleroderma autoantigens are uniquely fragmented by metal-catalyzed oxidation reactions: implications for pathogenesis. J Exp Med 1997, 185:71-79.

43. Wright WD, Roti Roti JL: Resolution of DNA topoisomerase II by twodimensional polyacrylamide gel electrophoresis and Western blotting. Anal Biochem 1992, 204:124-130.

44. Tamby MC, Servettaz A, Guilpain P, Tamas N, Berezne A, Batteux F, Reinbolt J, Guillevin L, Weill B, Mouthon L: Immunoblotting on HEp-2 cells increases the detection of antitopoisomerase 1 antibodies in patients with systemic sclerosis. Clin Immunol 2007, 123:82-88.

45. Servettaz A, Tamby MC, Guilpain P, Reinbolt J, Garcia de la Peña-Lefebvre $P$, Allanore Y, Kahan A, Meyer O, Guillevin L, Mouthon L: Anti-endothelial cell 
antibodies from patients with limited cutaneous systemic sclerosis bind to centromeric protein B (CENP-B). Clin Immunol 2006, 120:212-219.

46. Kuwana M, Kaburaki J, Medsger TA Jr, Wright TM: An immunodominant epitope on DNA topoisomerase I is conformational in nature: heterogeneity in its recognition by systemic sclerosis sera. Arthritis Rheum 1999, 42:1179-1188.

47. Kuwana M, Kimura K, Kawakami Y: Identification of an immunodominant epitope on RNA polymerase III recognized by systemic sclerosis sera: application to enzyme-linked immunosorbent assay. Arthritis Rheum 2002, 46:2742-2747.

doi:10.1186/ar3336

Cite this article as: Bussone et al:: Identification of new autoantibody specificities directed at proteins involved in the transforming growth factor $\beta$ pathway in patients with systemic sclerosis. Arthritis Research \& Therapy 2011 13:R74.

\section{Submit your next manuscript to BioMed Central} and take full advantage of:

- Convenient online submission

- Thorough peer review

- No space constraints or color figure charges

- Immediate publication on acceptance

- Inclusion in PubMed, CAS, Scopus and Google Scholar

- Research which is freely available for redistribution

Submit your manuscript at www.biomedcentral.com/submit 